\title{
Myeloperoxidase modulates lung epithelial responses to pro-inflammatory agents
}

\author{
A. Haegens*, J.H.J. Vernooy*, P. Heeringa\#", B.T. Mossman ${ }^{\star}$ and E.F.M. Wouters*
}

\begin{abstract}
During extensive inflammation, neutrophils undergo secondary necrosis causing myeloperoxidase (MPO) release that may damage resident lung cells. Recent observations suggest that MPO has pro-inflammatory properties, independent of its enzymatic activity. The aims of the present study were to characterise MPO internalisation by lung epithelial cells and to investigate the effect of MPO on oxidative stress, DNA damage and cytokine production by lung epithelial cells.
\end{abstract}

Human alveolar and bronchial epithelial cells were stimulated with MPO, with or without priming the cells with pro-inflammatory stimuli. MPO protein was detected in the cell cytoplasm. Expression of haemoxygenase (HO)-1 and DNA strand breakage were determined. The production of interleukin (IL)-8 and -6 were measured.

Analyses of MPO-stimulated cells demonstrated MPO presence in the cells. HO-1 expression was increased after MPO stimulation and increased further when cells were primed before MPO stimulation. MPO exposure also induced DNA strand breakage. Interestingly, MPO inhibited IL-8 production in bronchial, but not alveolar epithelium.

In conclusion, alveolar and bronchial epithelial cells can internalise myeloperoxidase. Stimulation with myeloperoxidase increases haemoxygenase-1 expression and DNA strand breakage, suggesting cell damaging capacity of myeloperoxidase. In addition, myeloperoxidase inhibited interleukin-8 production by bronchial epithelial cells, indicating a negative feedback loop for neutrophil recruitment.

KEYWORDS: Inflammation, myeloperoxidase, neutrophilia, oxidative stress

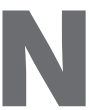
eutrophilia is a feature common to a number of inflammatory lung diseases, including chronic obstructive pulmonary disease (COPD) [1], asbestosis [2], idiopathic pulmonary fibrosis [3] and adult respiratory distress syndrome [4], although the agents and events leading to the development of these diseases are very different. Independently of the cause of the chemotactic gradient, neutrophils are activated during their recruitment to the lung and release the contents of their granula into the pulmonary compartment. Excess amounts of neutrophils can lead to secondary necrosis of neutrophils as a result of inefficient clearance of apoptotic neutrophils by macrophages. During secondary necrosis, neutrophils release their lysosomal constituents, which possibly affect resident lung cells [5].

Currently, over 50 neutrophil-derived toxins have been identified, including proteolytic enzymes and bacteriacidal proteins. The haem protein, myeloperoxidase (MPO), is the most abundant protein in neutrophils and represents
$5 \%$ of their total protein content [6]. MPO is synthesised as a precursor during myeloid differentiation in bone marrow, and its processing is completed before neutrophils enter the circulation [7-9]. A hallmark of neutrophil activation is their respiratory burst, in which MPO plays a central role [10]. MPO catalyses the conversion of hydrogen peroxide $\left(\mathrm{H}_{2} \mathrm{O}_{2}\right)$ and chloride ions into hypochlorous acid $(\mathrm{HOCl})$ and, therefore, it is an important enzyme in the host defence against bacteria, viruses and fungi [10]. MPO may also damage tissue by its production of $\mathrm{HOCl}$ and other reactive oxidants. $\mathrm{HOCl}$ production by MPO leads to the formation of chlorotyrosine residues, a marker of neutrophilic inflammation [11]. Nitric oxide and nitrite also serve as biological substrates of $\mathrm{MPO}$, leading to the formation of nitrogen dioxide $\left(\mathrm{NO}_{2}\right) . \mathrm{NO}_{2}$ promotes protein nitration, lipid peroxidation and the oxidation of tyrosine yielding nitrotyrosine, a post-translational modification and a contributor of inflammatory disease [12]. In addition to its role as a catalytically active protein generating reactive oxidants, MPO recently has
AFFILIATIONS

*Dept of Respiratory Medicine, University Hospital Maastricht, Maastricht, and

\# Dept of Pathology and Laboratory Medicine, University Medical Center Groningen, Groningen, The Netherlands.

"Dept of Pathology, University of Vermont, Burlington, VT, USA

\section{CORRESPONDENCE}

J.H.J. Vernooy

Dept of Respiratory Medicine University Hospital Maastricht

P.0. Box 5800

NL-6202 AZ Maastricht

The Netherlands

Fax: 31433875051

E-mail: j.vernooy@pul.unimaas.nl

Received:

March 122007

Accepted after revision:

November 152007

SUPPORT STATEMENT

$P$. Heeringa is supported by a grant from the Dutch Organization of

Scientific Research (NWO VIDI grant 917.66.341)

STATEMENT OF INTEREST

None declared.

European Respiratory Journa

Print ISSN 0903-1936

Online ISSN 1399-3003 
been shown to elicit pro-inflammatory properties independent of its enzymatic activity. MPO was demonstrated to associate with the outer membrane of neutrophils by binding to CD11b/ CD18 integrins, which are known to be linked to neutrophil activation [13]. In this manner, MPO may contribute to neutrophil recruitment to sites of inflammation. In addition, MPO stimulates the production of tumour necrosis factor- $\alpha$ and interferon- $\alpha / \beta$ by peritoneal macrophages and thereby enhances their killing of target cells [14]. Whether MPO released from neutrophils affects resident lung cells and their responses in the absence or presence of an initial inflammatory trigger is unknown.

Reactive oxidant species can be produced by MPO and, since haemoxygenase (HO)-1 is an indirect marker of oxidative stress, the authors hypothesised that MPO exposure would lead to HO-1 upregulation and an increase in DNA cell damage. Neutrophil recruitment is induced by the production of chemoattractants at an inflammatory site; therefore, the production of interleukin (IL)- 8 and -6 by lung epithelial cells was investigated.

In the present study, bronchial and alveolar epithelial cells under basal (homeostatic) and primed conditions were used. These primed conditions were created by stimulating cells with lipopolysaccharide (LPS) to mimic lung infection and with asbestos to mimic asbestosis; phorbol 12-myristate 13acetate (PMA) was used as positive control. The aims of the present study were to: 1 ) characterise MPO internalisation by lung epithelial cells; and 2) to investigate the effect of MPO on oxidative stress, DNA damage and IL- 8 and -6 production by lung epithelial cells under basal and inflammatory conditions.

\section{MATERIALS AND METHODS Cells and stimulation}

Human bronchial epithelial cells (Beas-2B) and a human transformed alveolar epithelial cell line (A549) were obtained from the American Type Culture Collection (Manassas, VA, USA) and cultured in RMPI 1,640 (Gibco, Grand Island, NY, USA) containing $10 \%$ foetal bovine serum (FBS; Biochrome, Berlin, Germany), L-glutamine (2 $\mathrm{mM})$ and penicillin/streptomycin (both Invitrogen, Grand Island, NY, USA). Tissue culture surfaces for the Beas-2B cells were coated with LHC basal medium containing $10 \%$ bovine serum albumin (BSA; both Biosource International, Camarillo, CA, USA), $1 \mathrm{mg} \cdot \mathrm{mL}^{-1}$ fibronectin and $2.9 \mathrm{mg} \cdot \mathrm{mL}^{-1}$ bovine collagen, type 1 (both BD Biosciences, Bedford, MA, USA). Cells were plated at a density of 20,000 cells $\cdot \mathrm{cm}^{-2}$ for analyses of IL- 6 and -8 production, and at a density of 13,000 cells $\cdot \mathrm{cm}^{-2}$ for immunofluorescence staining on coverslips and Western blot analysis. Growth medium was replaced by medium containing 0.5\% FBS 18$24 \mathrm{~h}$ prior to stimulation. LPS (Escherichia coli, 055:B5; Sigma, St Louis, MO, USA), PMA (Sigma) and MPO (Calbiochem, San Diego, CA, USA) stocks were prepared and stored at $-20^{\circ} \mathrm{C}$. The National Institute of Environmental Health Sciences processed crocidolite, and chrysotile asbestos was always used fresh. Asbestos was weighed, UV-sterilised, suspended in $1 \mathrm{mg} \cdot \mathrm{mL}^{-1}$ in tissue culture medium and triturated eight times through a 22-gauge needle to obtain a homogeneous suspension. When LPS, PMA or asbestos stimulation was followed by MPO stimulation, media from controls and pre-stimulated cells was replaced with fresh MPO containing RPMI 1640 with
$0.5 \%$ FBS. Supernatants were harvested and stored at $-20^{\circ} \mathrm{C}$ until they were used for ELISA.

\section{MPO detection}

Immunofluorescence staining in vitro

Cells were washed twice with ice-cold PBS followed by fixation with $4 \%$ paraformaldehyde for $5 \mathrm{~min}$. Cells were permeabalised with $100 \%$ ice-cold methanol for $3 \mathrm{~min}$ followed by two washes with PBS and blocking with $1 \%$

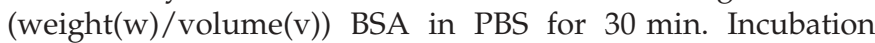
with rabbit anti-human MPO (0398; DAKO, Glostrup, Denmark) with $0.1 \%(\mathrm{w} / \mathrm{v})$ BSA in PBS for 60 min was followed by incubation with goat anti-rabbit Texas Red (401007; Southern Biotechnology Associates, Birmingham, AL, USA) for $30 \mathrm{~min}$ in the dark. Nuclei were stained with diamidino-2phenylindole. Negative controls obtained by omitting primary antibody revealed no staining.

\section{Immunohistochemistry on lung sections}

Peripheral lung specimens of patients undergoing lung surgery were processed immediately following resection by fixation in $10 \%$ phosphate-buffered formalin prior to embedding in paraffin. In order to verify that epithelial cells were affected by released MPO, lung sections $(3 \mu \mathrm{m})$ from COPD or asbestosis patients were cut and deparafinised three times for 5 min in Ultraclear (J.T. Baker, Deventer, The Netherlands), followed by two $5 \mathrm{~min}$ incubations with $100 \%$ ethanol. Endogenous peroxidase was blocked by incubation with $0.6 \% \mathrm{H}_{2} \mathrm{O}_{2}$ in methanol for $15 \mathrm{~min}$ followed by hydrating through ethanols $(80,70$ and $50 \%)$ to water. The sections were equilibrated in tris-buffered saline (TBS; $\mathrm{pH} 7.6$ ) for $5 \mathrm{~min}$ followed by $30 \mathrm{~min}$ blocking with $20 \%$ normal swine serum in TBS-Tween20 $(0.01 \%)$ with $1 \%(\mathrm{w} / \mathrm{v})$ BSA. A rabbit antihuman MPO (0398; DAKO) primary antibody diluted in TBSTween $20(0.01 \%)$ with $1 \%(\mathrm{w} / \mathrm{v})$ BSA was incubated for $45 \mathrm{~min}$ followed by $30 \mathrm{~min}$ incubation with a swine anti-rabbit biotinylated secondary antibody (E0413; DAKO) and avidinbiotinylated horseradish peroxidase (K0377; DAKO). Enzymatic reactivity was visualised with HistoGreen (Linaris, Wertheim, Germany). Negative controls obtained by omitting primary antibody revealed no staining.

\section{Preparation of membrane and cytoplasmic fractions}

Cells were placed on ice and washed twice with ice-cold PBS. Cells were suspended in lysis buffer ( $\mathrm{pH} 8 ; 25 \mathrm{mM}$ Tris, $2 \mathrm{mM}$ $\mathrm{MgCl}_{2}, 5 \mathrm{mM} \mathrm{KCl}, 1 \mathrm{mM}$ sodium-orthovanadate, $1 \mathrm{mM}$ phenylmethyl sulfonyl fluoride, $10 \mathrm{mM} \mathrm{NaF}, 10 \mu \mathrm{g} \cdot \mathrm{mL}^{-1}$ aprotinin, $10 \mu \mathrm{g} \cdot \mathrm{mL}^{-1}$ leupeptin), homogenised and vortexed for $10 \mathrm{~s}$. Cell nuclei were centrifuged for $10 \mathrm{~min}$ at $1,000 \times g$ at $4{ }^{\circ} \mathrm{C}$. Supernatant was transferred to a new tube and the membrane fraction was centrifuged for $30 \mathrm{~min}$ at $20,800 \times g$ at $4{ }^{\circ} \mathrm{C}$. Cytoplasmic fractions were transferred to new tubes and the membrane fractions were resuspended in lysis buffer. A portion of both fractions was saved for protein determination, prior to the addition of $4 \times$ concentration Laemmli sample buffer ( $\mathrm{pH} 6.8 ; 0.25 \mathrm{M}$ Tris- $\mathrm{HCl}, 8 \%(\mathrm{w} / \mathrm{v})$ sodium dodecyl sulphate, $40 \%$ (v/v) glycerol, $0.4 \mathrm{M}$ dithiothreitol and $0.04 \%$ $(\mathrm{w} / \mathrm{v})$ bromophenol blue). Samples were then boiled for $5 \mathrm{~min}$ and stored at $-20^{\circ} \mathrm{C}$. 


\section{Preparation of nuclear extracts}

Cells were placed on ice and washed twice with ice-cold PBS. They were then suspended in cytoplasmic buffer ( $\mathrm{pH} 7.6$; $10 \mathrm{mM}$ Tris- $\mathrm{HCl}, 10 \mathrm{mM} \mathrm{KCl}, 1.5 \mathrm{mM} \mathrm{MgCl}_{2}, 1 \%$ Triton X-100, $1 \mathrm{mM}$ dithiothreitol, $0.2 \mathrm{mM}$ sodium-orthovanadate, $0.4 \mathrm{mM}$ phenylmethyl sulfonyl fluoride, $10 \mu \mathrm{g} \cdot \mathrm{mL}^{-1}$ leupeptin, $0.2 \mathrm{mM}$ $\mathrm{NaF}$ ), vortexed vigorously and placed on ice for $15 \mathrm{~min}$. Cell nuclei were then centrifuged for $5 \mathrm{~min}$ at $10,000 \times \mathrm{g}$ at $4^{\circ} \mathrm{C}$. Supernatant was transferred to a new tube and cell nuclei were washed once in cytoplasmic buffer by suspending, vortexing and centrifugation. The supernatant was discarded and cell nuclei were suspended in nuclear buffer (pH 7.6; $20 \mathrm{mM}$ Tris$\mathrm{HCl}, 0.4 \mathrm{mM} \mathrm{KCl}, 1.5 \mathrm{mM} \mathrm{MgCl}_{2}, 10 \%$ glycerol, $1 \mathrm{mM}$ dithiothreitol, $0.2 \mathrm{mM}$ sodium-orthovanadate, $0.4 \mathrm{mM}$ phenylmethyl sulfonyl fluoride, $10 \mu \mathrm{g} \cdot \mathrm{mL}^{-1}$ leupeptin, $0.2 \mathrm{mM} \mathrm{NaF}$ ). Cells were placed in a vertical rotator at $4^{\circ} \mathrm{C}$ for $30 \mathrm{~min}$ followed by centrifugation for $20 \mathrm{~min}$ at $14,000 \times g$ at $4^{\circ} \mathrm{C}$. The supernatant, containing the nuclear proteins, was transferred to a new tube. A portion of the supernatant was saved for protein determination, prior to the addition of $4 \times$ concentration Laemmli sample buffer. Samples were then boiled for $5 \mathrm{~min}$ and stored at $-20^{\circ} \mathrm{C}$.

\section{Western blot analysis}

Protein concentrations were determined using the Bradford protein assay according to the manufacturer's protocol (BioRad, Hercules, CA, USA). Protein was loaded (10 $\mu \mathrm{g}$ for MPO and AP-1, $5 \mu \mathrm{g}$ for p65, per lane) and separated on a polyacrylamide gel (Mini Protean 3 System; Bio-Rad), followed by transfer to a $0.45-\mu \mathrm{m}$ nitrocellulose membrane (Bio-Rad) by electroblotting. The membrane was blocked for $1 \mathrm{~h}$ at room temperature in $5 \%(\mathrm{w} / \mathrm{v})$ nonfat, dried milk diluted in TBSTween20 (0.05\%). Nitrocellulose blots were washed in TBSTween $20(0.05 \%)$ followed by overnight incubation at $4{ }^{\circ} \mathrm{C}$, with primary antibody (rabbit anti-MPO (0398; DAKO); rabbit antip65 (C-20 sc-372; Santa Cruz Biotechnology, Santa Cruz, CA, USA); rabbit anti-phospho c-Jun (Ser63) II (9261; Cell Signaling, Beverly, MA, USA)). After three washes of 20 min each, the blots were probed with horseradish peroxidase-conjugated anti-rabbit antibody (PI-1000; Vector Laboratories, Burlingame, CA, USA) and visualised by chemiluminesence using Supersignal ${ }_{\circledR}$ WestPico Chemiluminescent Substrate (Pierce Biotechnology, Rockford, IL, USA) according to the manufacturers' instructions and exposed to film (Biomax light film; Kodak, Chalon-sur-Saone, France).

\section{Quantitative PCR detection of HO-1 and IL-8 expression}

Whole cell RNA was isolated using the RNeasy Mini Kit (Qiagen Inc., Valencia, CA, USA) according to manufacturer's protocol. Total RNA was reverse transcribed, using the Abgene Kit (Abgene, Epsom, UK) with random hexamer primers, and the resulting cDNA was amplified by real-time PCR using the MJ Research Opticon 2 (Bio-Rad) with the following primers: HO-1, (forward) 5'-CCAGCAACAAAGTGCAAGATTC-3', (reverse) 5'-CTGCAGGAACTGAGGATGCTG-3'; IL-8, (F) 5'GGACAAGAGCCAGGAAGAAA-3', (R)-5'-AAATTTGGGGTGGAAAGGTT-3'; $\beta$-actin, (F) 5'-GGGACCTGACCGACTACCTC, (R) 5'GGGCGATGATCTTGATCTTC. Each PCR reaction contained $1 \times$ concentration $S Y B R_{\circledast}$ Green PCR master mix (Applied Biosystems, Foster City, CA, USA) and $0.3 \mu \mathrm{M}$ each of the forward and reverse primers. Following an initial $10 \mathrm{~min}$ incubation at $95^{\circ} \mathrm{C}$, thermal cycling was performed using 45 cycles of $94^{\circ} \mathrm{C}$ for $15 \mathrm{~s}, 60^{\circ} \mathrm{C}$ for $30 \mathrm{~s}$ and $72^{\circ} \mathrm{C}$ for $30 \mathrm{~s}$. Gene expression was quantified using standard curves for the respective cDNA products. All changes in $\mathrm{HO}-1$ and IL-8 cDNA levels were normalised to changes in $\beta$-actin cDNA.

\section{Single-cell gel electrophoresis: Comet assay}

DNA strand breakage in epithelial cell preparations was assayed immediately after cell isolation using the Comet assay. Fully frosted slides were coated with agarose and stored overnight at $4{ }^{\circ} \mathrm{C}$. Epithelial lung cells were isolated by trypsinisation and centrifugation, and resuspended in $20 \mu \mathrm{L}$ of cold PBS. Cells were mixed with $70 \mu \mathrm{L} 0.5 \%$ low-melting point agarose and added to the slides, on top of the first agarose layer, using a cover glass. Slides were stored at $4{ }^{\circ} \mathrm{C}$ for $3 \mathrm{~min}$ to allow solidification, cover glasses were removed and slides were immersed in lysis buffer $(\mathrm{pH} 10 ; 2.5 \mathrm{M} \mathrm{NaCl}$, $100 \mathrm{mM}$ EDTA, $10 \mathrm{mM}$ tris, $250 \mathrm{mM} \mathrm{NaOH}$ ) and stored overnight at $4{ }^{\circ} \mathrm{C}$. The following day, slides were rinsed with distilled water and placed in an electrophoresis tank filled with ice-cold electrophoresis buffer $(\mathrm{pH} \mathrm{13;} 300 \mathrm{mM} \mathrm{NaOH}, 1 \mathrm{mM}$ EDTA) for $20 \mathrm{~min}$. Electrophoresis was conducted at $300 \mathrm{~mA}$ and $25 \mathrm{~V}$ for $20 \mathrm{~min}$. Slides were neutralised three times for 10 min using neutralisation buffer ( $\mathrm{pH} 7.5$; $0.4 \mathrm{M}$ Tris). All steps after cell lysis were performed in the dark or under dimmed red light to prevent additional DNA damage.

\section{ELISA}

IL-6 and IL-8 protein levels in culture supernatants were assayed in triplicate using ELISA kits specific for IL-6 and IL-8 (Sanquin, Amsterdam, The Netherlands) according to the manufacturer's instructions. The lower detection limit of IL-6 was $3.8 \mathrm{pg} \cdot \mathrm{mL}^{-1}$ and $9.0 \mathrm{pg} \cdot \mathrm{mL}^{-1}$ for IL-8.

\section{Statistical analyses}

Data are expressed as mean \pm SEM, unless stated otherwise. Statistical comparisons among experimental groups were performed by ANOVA and a $\mathrm{p}$-value $\leqslant 0.05$ was considered to be statistically significant.

\section{RESULTS \\ MPO uptake by human bronchial and alveolar epithelial cells}

Bronchial (Beas-2B) as well as alveolar (A549) epithelial cells were stimulated with $\mathrm{MPO}$ in order to determine the timeframe of MPO internalisation by these cells. Immunofluorescense staining demonstrated MPO protein on A549 and Beas-2B cells (figs $1 \mathrm{a}$ and b) after $24 \mathrm{~h}$ of stimulation. Western blot analysis (fig. 1e) of cytoplasmic protein fractions showed that MPO was detectable in A549 cells after $30 \mathrm{~min}$ of stimulation and was still internalised after $24 \mathrm{~h}$ of stimulation. In contrast to A549 cells, MPO content in Beas-2B cells (fig. 1f) peaked after $4 \mathrm{~h}$ of stimulation and decreased again after $24 \mathrm{~h}$. Priming of the cells with either LPS or PMA had no effect on intracellular levels of MPO (data not shown). In order to confirm the in vitro data on MPO uptake by lung epithelial cells, MPO was localised in human lung sections of patients with pulmonary neutrophilia suffering from COPD, acute bronchopneumonia and asbestosis. Table 1 shows subject characteristics. Figures $1 \mathrm{a}-\mathrm{d}$ illustrate representative MPO stainings and demonstrate that all cells in close proximity to 
extravasated and degranulated neutrophils are possibly target cells. Endothelial cells near neutrophils that are not fully activated and have not migrated into the inflammatory site do not contain MPO (fig. 2b)

\section{MPO exposure after primary stimulus results in increased oxidative stress}

In order to investigate the influence of $\mathrm{MPO}$ on oxidative stress as a result of pro-inflammatory stimuli, cells were stimulated with MPO alone or primed with PMA, LPS or crocidolite or chrysotile asbestos, followed by stimulation with MPO. MPO exposure of A549 (fig. 3a) and Beas-2B (fig. 3b) cells resulted in an increased HO-1 expression, an indirect marker of oxidative stress. LPS was the only pro-inflammatory stimulus, besides from MPO, which could induce $\mathrm{HO}-1$ expression significantly in A549 cells. MPO stimulation of cells primed with PMA or asbestos resulted in a significant increase of HO-1 expression as compared with priming control A549 cells (fig. 3a). In Beas-2B cells only asbestos priming resulted in increased HO-1 expression. Asbestos priming followed by MPO stimulation had a synergistic effect on HO-1 expression in Beas-2B cells (fig. 3b).

\section{MPO stimulation increases DNA damage}

$\mathrm{MPO}$ produces damaging reactive oxidants, such as $\mathrm{HOCl}$ and $\mathrm{NO}_{2}$. A Comet assay was used to detect DNA strand break formation in lung epithelial cells after MPO exposure. MPO exposure resulted in a temporary increase in DNA strand breakage in both A549 (fig. 4a) and Beas-2B (fig. 4b) cells, starting $10 \mathrm{~min}$ after MPO exposure. DNA damage increased significantly after $20 \mathrm{~min}$ and, after 30-min MPO exposure, the DNA strand breakage started to decline.
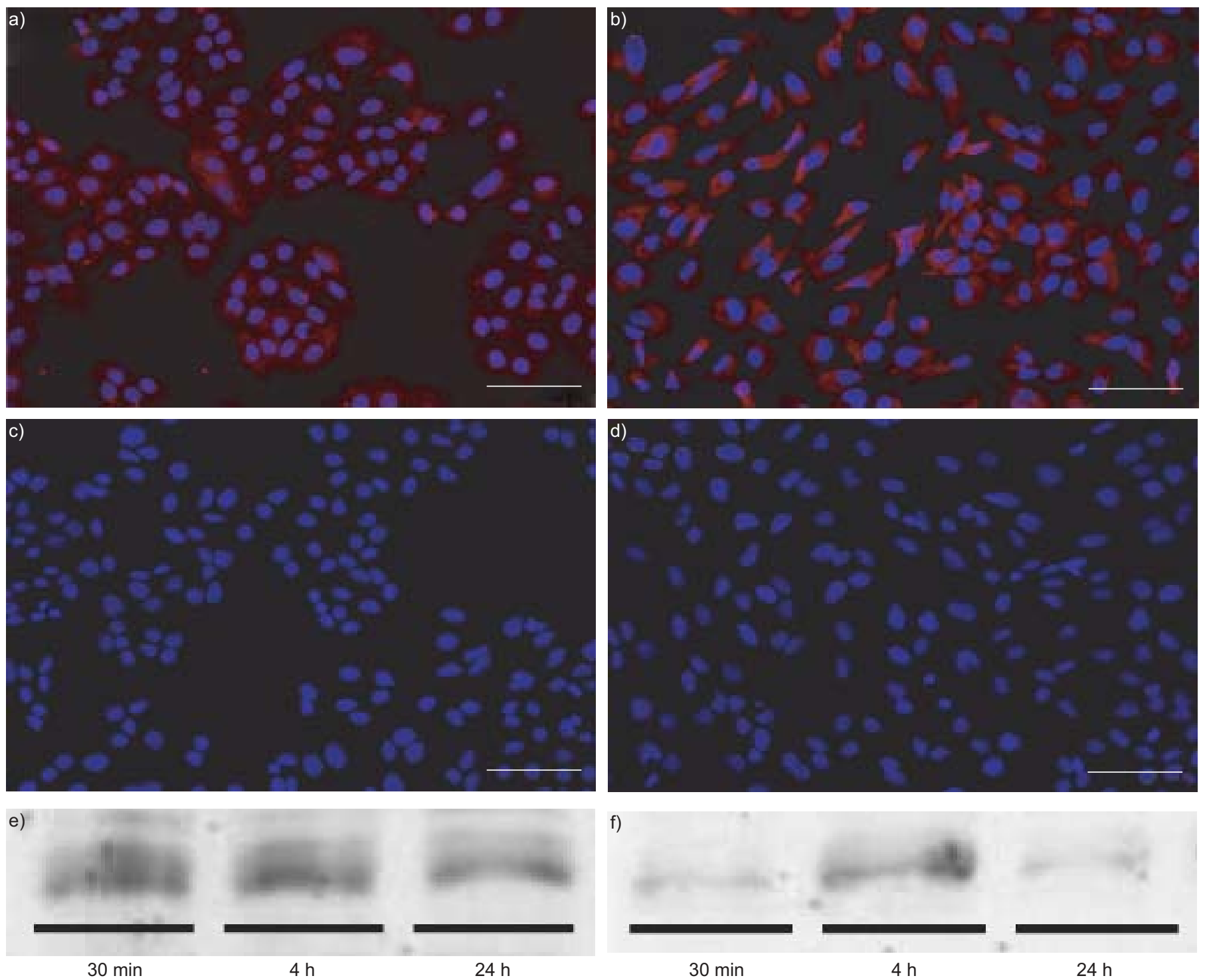

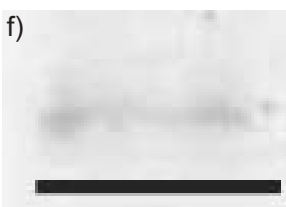

$30 \min$

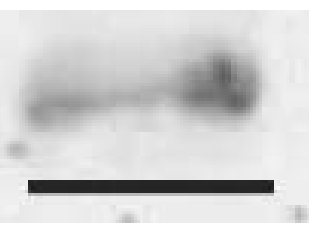

$4 \mathrm{~h}$

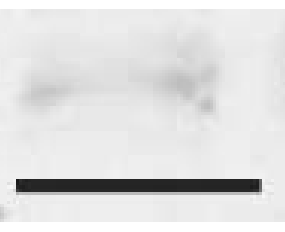

$24 \mathrm{~h}$

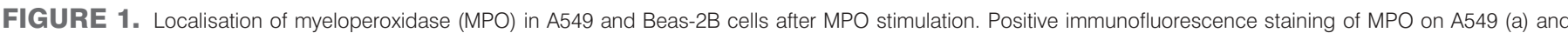

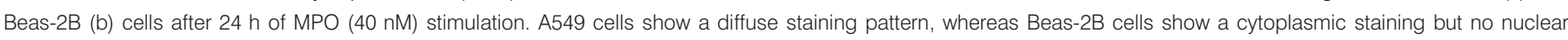

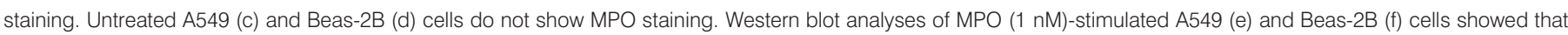
MPO was present in the cell cytoplasm $30 \mathrm{~min}$ after MPO stimulation, but did not accumulate after $24 \mathrm{~h}$. Scale bars $=25 \mu \mathrm{m}$. 

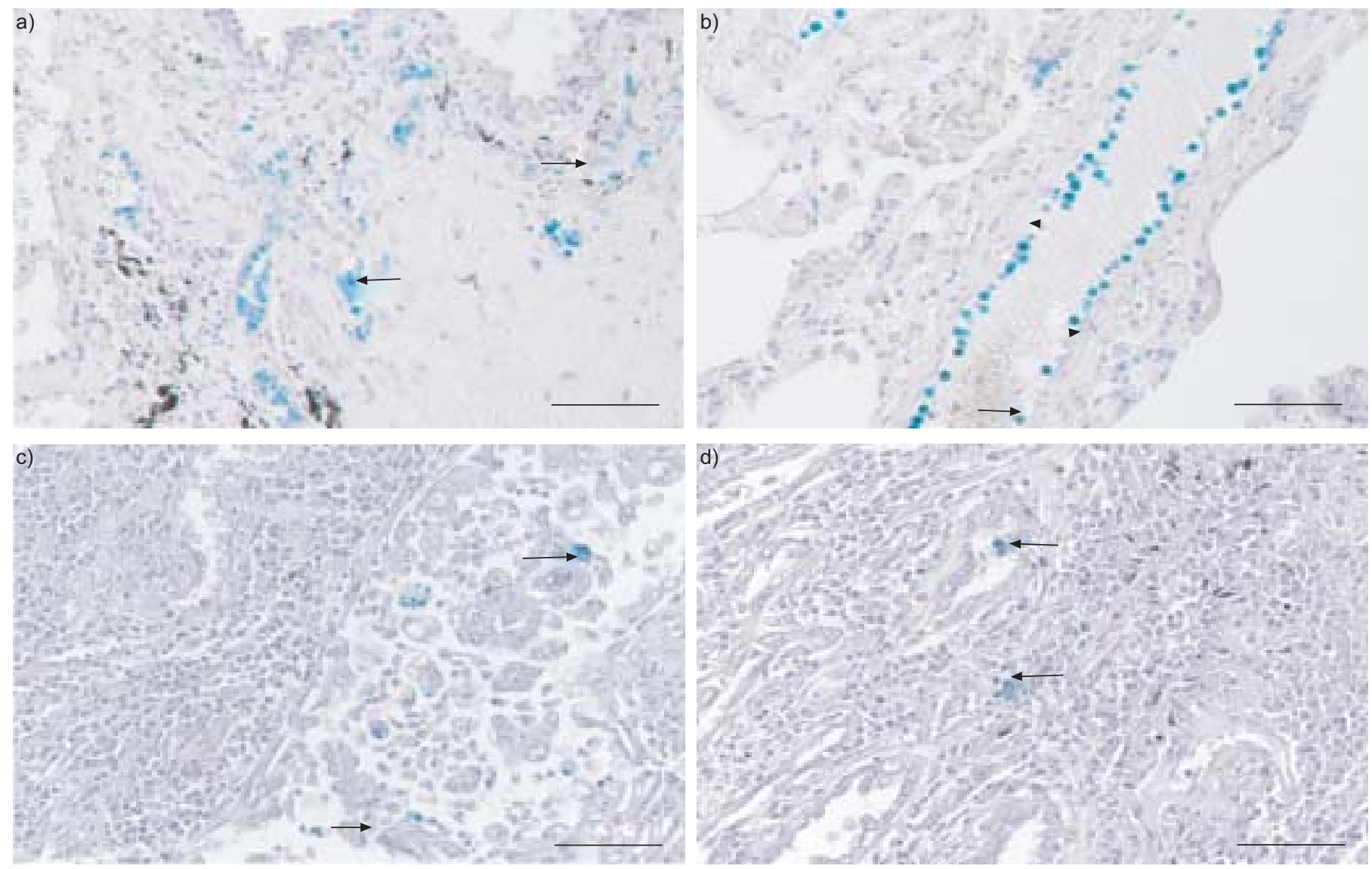

FIGURE 2. Representative immunostaining for myeloperoxidase (MPO) on human lung sections of chronic obstructive pulmonary disease (a, b) and asbestosis (c, d) Alveolar epithelial cells (arrows) in close proximity to degranulated neutrophils stained positive for MPO. Endothelial cells (arrowheads) near intravascular undegranulated neutrophils stained negative for MPO. Scale bars $=50 \mu \mathrm{m}$.

\begin{tabular}{cccc} 
TABLE 1 & $\begin{array}{l}\text { Subject characteristics of patients with acute } \\
\text { bronchopneumonia, chronic obstructive } \\
\text { pulmonary disease or asbestosis }\end{array}$ \\
Subject $^{\#}$ & Age yrs & Smoking status & Tissue collection \\
\hline COPD & & & \\
1 & 70 & Ex-smoker & LVRS \\
2 & 73 & Current & Tumour resection \\
3 & 66 & Ex-smoker & Tumour resection \\
ABP & & Ex-smoker & Tumour resection \\
1 & 75 & Ex-smoker & Tumour resection \\
2 & 72 & & \\
Asbestosis & & Unknown & Tumour resection \\
1 & 51 & Unknown & Tumour resection \\
2 & 70 & Unknown & Tumour resection \\
3 & 77 & & \\
\hline
\end{tabular}

COPD: chronic obstructive pulmonary disease; ABP: acute bronchopneumonia; LVRS: lung volume reduction surgery. ${ }^{*}$ : all male; ": defined as having ceased smoking $>6$ months before the start of the study.

\section{IL-8 and IL-6 production decreased after MPO stimulation of Beas-2B cells}

In order to investigate the influence of MPO on IL-8 and IL-6 production under basal and pro-inflammatory conditions, cells were primed with PMA, LPS, crocidolite or chrysotile asbestos or medium alone, followed by stimulation with MPO. Figure 5a shows that all pro-inflammatory stimuli caused an increase in IL-8 production by Beas-2B cells. Stimulation with MPO alone or after priming with PMA decreased IL-8 production significantly. These significant results were confirmed by analysis of IL-8 expression levels by quantitative PCR (fig. 5b). IL-6 production by Beas-2B cells had a similar pattern as IL-8, although decreases were nonsignificant (fig. 5c). MPO exposure of A549 cells, under basal and inflammatory conditions, did not influence IL- 8 production, and IL-6 production was undetectable (data not shown).

\section{Activation of cell signalling pathways following cell stimulation}

The promoter regions of HO-1, IL-8 and IL-6 have binding sites for the transcription factors, $\mathrm{AP}-1$ and nuclear factor (NF)- $\mathrm{\kappa B}$. In order to investigate whether MPO affects $\mathrm{HO}-1$ expression and IL- 8 and IL- 6 production via transcription factors AP-1 and NF- $\kappa \mathrm{B}$ in lung epithelial cells, A549 and Beas-2B cells were stimulated with LPS, PMA, asbestos or MPO, and AP-1 and NF- $\kappa \mathrm{B}$ transcriptional activity was determined by Western blot 

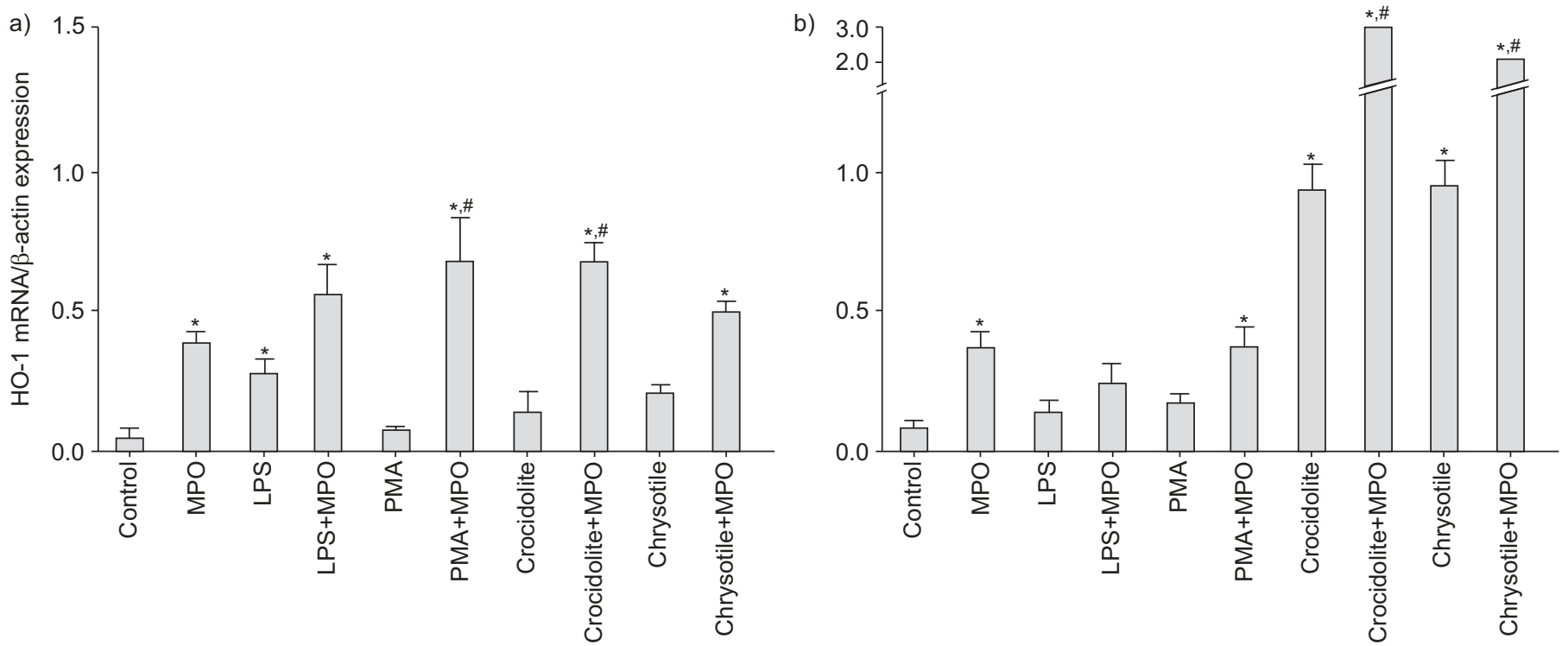

FIGURE 3. Quantitative PCR analysis of haemoxygenase (HO)-1 messenger RNA normalised against $\beta$-actin expression after myeloperoxidase (MPO) stimulation in a) A549 and b) Beas-2B cells under basal and pro-inflammatory conditions. Cells were stimulated with MPO (10 nM) for $24 \mathrm{~h}$ or primed for $12 \mathrm{~h}$ with lipopolysaccharide (LPS; $3 \mu \mathrm{g} \cdot \mathrm{mL}^{-1}$ ), phorbol 12-myristate 13-acetate (PMA; $10 \mathrm{ng} \cdot \mathrm{mL}^{-1}$ or $20 \mathrm{ng} \cdot \mathrm{mL}^{-1}$ for A549 and Beas-2B cells, respectively) or crocidolite/chrysotile asbestos $\left(6.25 \mu \mathrm{g} \cdot \mathrm{cm}^{-2}\right.$ ) followed by 12-h MPO stimulation. Representative data of two individual experiments are shown. Data are presented as mean \pm SEM. *: $p \leqslant 0.05$ versus unstimulated cells: $\#: p \leqslant 0.05$ versus primed control.

analyses. A 60-min stimulation of A549 cells with MPO did not

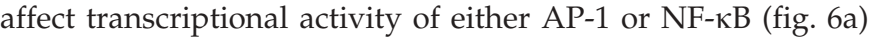
or Beas-2B cells (data not shown).

Increased activity of NF- $\mathrm{B}$, measured by $\mathrm{p} 65$ translocation, in A549 (fig. 6b) and Beas-2B cells (data not shown) was found after 60-min stimulation with LPS, PMA or crocidolite asbestos.

\section{DISCUSSION}

The haem protein MPO is the most abundant protein in neutrophils [6] and, therefore, an important enzyme in innate immunity [10]. Recently, MPO has been shown to elicit pro-inflammatory properties independent of its catalytic properties. The present study is the first to report the effects of MPO on human lung epithelial cells and their responses in the absence or presence of an initial inflammatory trigger.

Using two techniques, the present authors demonstrated MPO uptake by bronchial and alveolar epithelium after MPO stimulation. YANG et al. [15] reported that Beas-2B cells showed similar staining patterns as small airway epithelial cells demonstrating MPO in the cytoplasm, but not in the nucleus. In contrast, A549 cells do not show a pronounced lack of nuclear staining. This suggests that MPO distribution after uptake varies between cell types. Neutrophils go through several stages of activation during the extravasation process. The majority of MPO content of neutrophils is released during

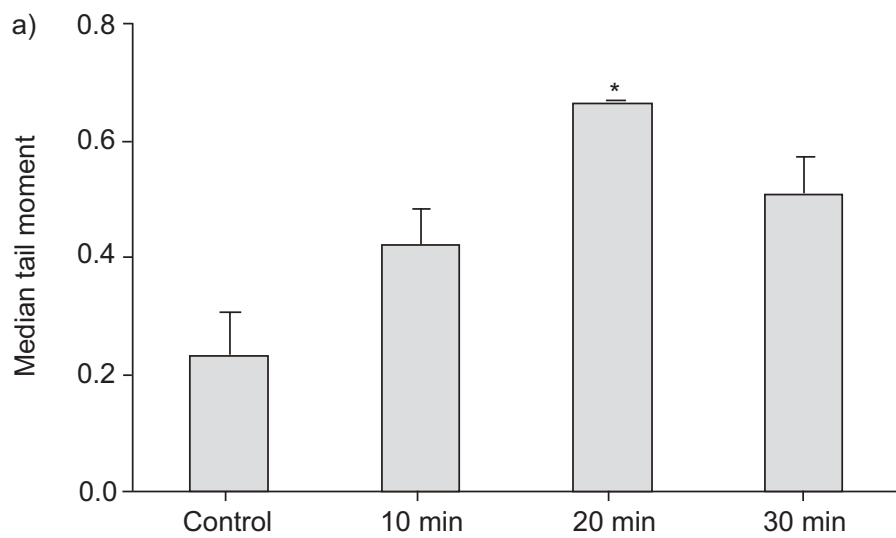

b)

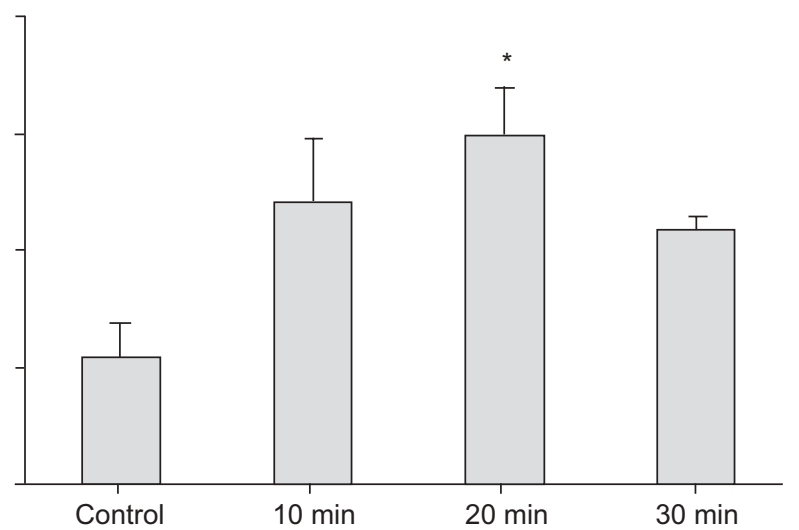

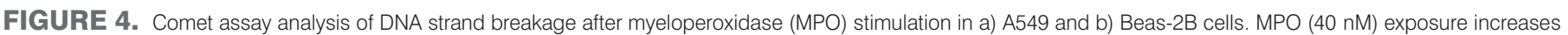

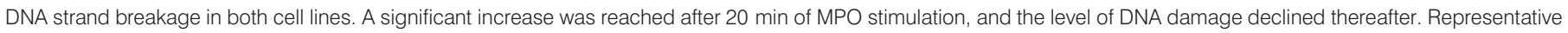
data of three individual experiments are shown. Data are presented as mean \pm SEM. ${ }^{*}: p \leqslant 0.05$ versus unstimulated cells. 

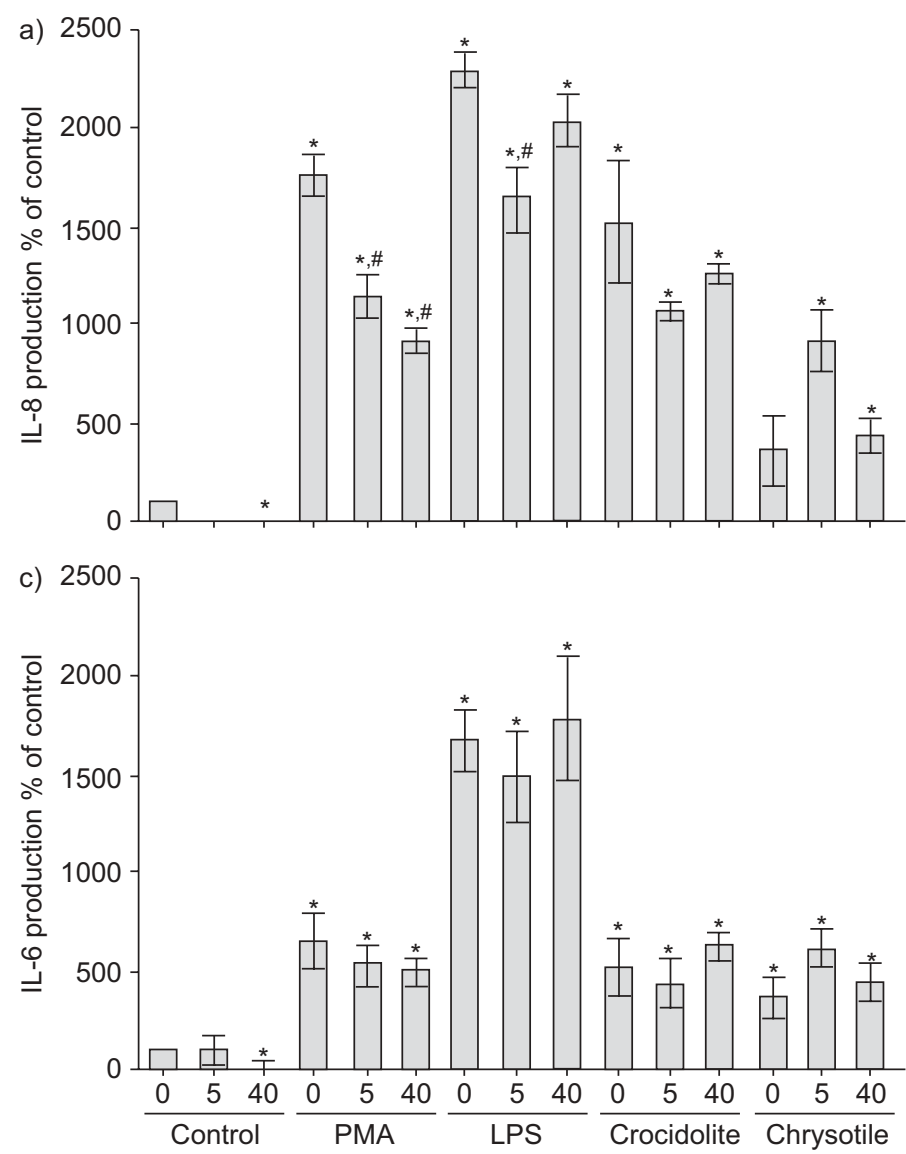

b) 0.4

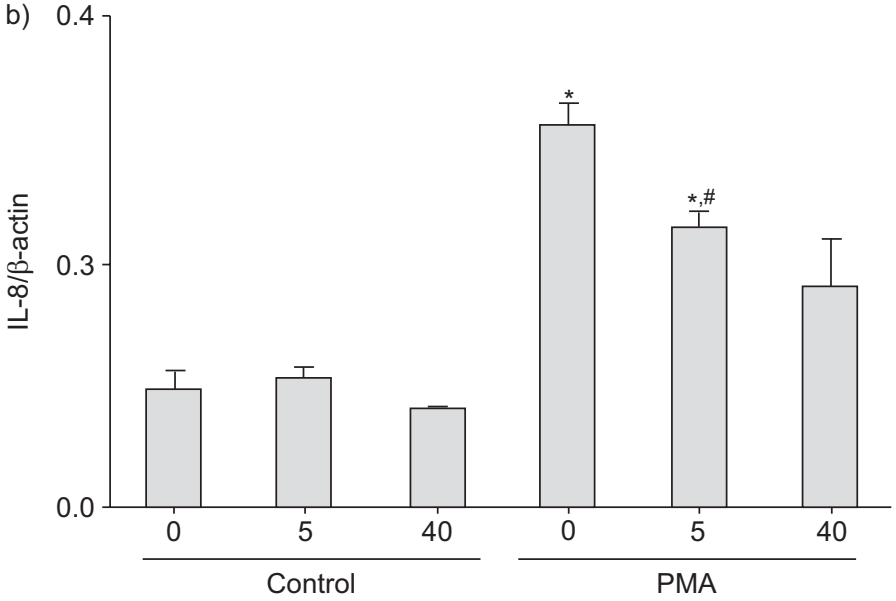

FIGURE 5. Detection of interleukin (IL)-8 production and expression and IL-6 production by Beas-2B cells under basal and pro-inflammatory conditions. Production of IL-8 (a) and IL-6 (c) was detected by ELISA and expression of IL-8 (b) was detected using quantitative PCR. Cells were stimulated with myeloperoxidase (MPO) for $24 \mathrm{~h}$, or primed for $24 \mathrm{~h}$ with lipopolysaccharide (LPS; $3 \mu \mathrm{g} \cdot \mathrm{mL}^{-1}$ ), phorbol 12-myristate 13-acetate (PMA; $10 \mathrm{ng} \cdot \mathrm{mL}^{-1}$ or $20 \mathrm{ng} \cdot \mathrm{mL}^{-1}$ for $\mathrm{A} 549$ and Beas-2B cells, respectively) or crocidolite/chrysotile asbestos $\left(6.25 \mu \mathrm{g} \cdot \mathrm{cm}^{-2}\right)$ followed by $24 \mathrm{~h}$ MPO stimulation. Representative data of three individual experiments are shown. Data are presented as mean \pm SEM. ${ }^{*}: p \leqslant 0.05$ versus

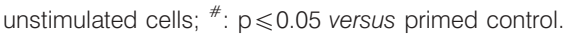

oxidative burst, when they are fully activated and have entered a site of inflammation [16]. By immunostaining human lung tissue from COPD, acute bronchopneumonia and asbestosis patients with active neutrophilia, the in vitro data is confirmed and demonstrates that not only epithelial cells, but all cells in close proximity to activated and degranulated neutrophils, are possible target cells for MPO. This is in accord with previous studies describing MPO uptake by other cell types, such as fibroblasts [17] and endothelial cells [18].

The enzymatic activity of MPO results in the formation of $\mathrm{HOCl}$, which is a potent oxidant with cell damaging capacities. An increase in lung epithelial cell DNA damage after incubation with purified MPO is demonstrated herein. This DNA damage is most likely due to $\mathrm{HOCl}$ production by MPO. HOCl-related normal bronchial epithelial cell damage has been reported previously [19] and confirms the present data from the Comet assay. In contrast to the present findings, a decrease in DNA damage was observed when MPO was added to cell cultures provided with an $\mathrm{H}_{2} \mathrm{O}_{2}$ generating system [20]. However, neutrophils and macrophages used in that study [20] produced reactive oxidant species themselves. It can therefore be speculated that these cell types are better protected against oxidative damage than the lung epithelium, since lung epithelial cells probably do not produce reactive oxidants at the same magnitude as neutrophils and macrophages [21].

HO-1 is an important cytoprotective enzyme and a widely accepted indirect marker of oxidative stress. The present data showed an increase in HO-1 expression by bronchial and alveolar epithelial cells after MPO stimulation. JANSSEN et al. [22] first reported that crocidolite asbestos exposure leads to a significant increase of HO-1 expression in human mesothelial cells, which has recently been confirmed in an animal model [23]. In the present study, it is shown that both crocidolite and chrysotile, an iron-free asbestos, stimulate HO-1 expression in Beas-2B cells. More striking was the finding of a synergistic effect of MPO stimulation after asbestos priming on $\mathrm{HO}-1$ expression in both cell lines, which was not demonstrated with LPS or PMA. The present authors speculate that $\mathrm{O}_{2}^{-}$or $\mathrm{H}_{2} \mathrm{O}_{2}$ released by frustrated phagocytosis of long asbestos fibres [24, 25] synergise with nitrosating or oxygen free radicals produced by MPO.

An increase in IL-8 and IL-6 production, both involved in the development of inflammation, after PMA or asbestos stimulation is demonstrated herein, which confirms previous findings [26-28]. In the present study, it is shown for the first time that MPO stimulation of PMA-primed Beas-2B cells results in a significant decrease of IL-8 production and a trend towards decreased IL- 6 production by Beas-2B cells. Additionally, the present data, demonstrating that under basal conditions MPO can inhibit the production of IL- 8 by Beas-2B cells, are novel. This may indicate a negative feedback loop for neutrophil recruitment. Cytokine production by A549 and Beas-2B cells is a serum-dependent event, as described previously [29] and, as the present experiments are performed under low serum 
a) p-c-Jun

b) p65
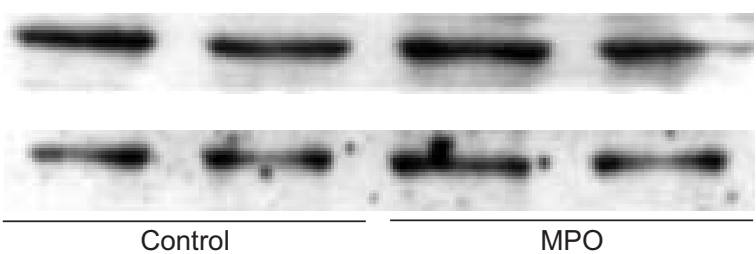

c)

c)

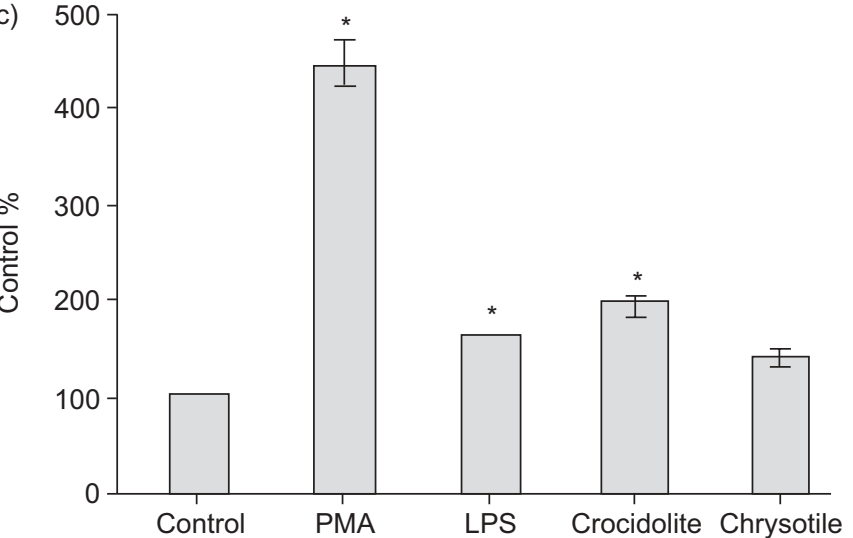

FIGURE 6. Western blot detection of a) p-c-Jun and b) p65 in A549 cells. Myeloperoxidase (MPO; $10 \mathrm{nM}$ ) stimulation for $60 \mathrm{~min}$ did not increase p65 translocation or c-Jun phosphorylation in A549 cells. c) p65 translocation is increased in A549 cells after 60-min stimulation with phorbol 12-myristate 13acetate (PMA; $10 \mathrm{ng} \cdot \mathrm{mL}^{-1}$ ), lipopolysaccharide (LPS; $3 \mu \mathrm{g} \cdot \mathrm{mL}^{-1}$ ) or crocidolite/ chrysotile asbestos $\left(6.25 \mu \mathrm{g} \cdot \mathrm{cm}^{-2}\right)$. Representative data of two individual experiments are shown. Data are presented as mean \pm SEM. *: $p \leqslant 0.05$ versus unstimulated cells.

conditions, this may explain why basal production of IL-6 by A549 cells was not detected.

Since IL-8 and IL-6 are both known to be NF-кB- and AP-1regulated genes [30, 31], and the $\mathrm{HO}-1$ promoter region contains NF- $\mathrm{KB}$ and AP-1 binding sites, the present authors hypothesised that MPO stimulation of A549 and Beas-2B would affect NF- $\kappa B$ or AP-1 transcriptional activity. Surprisingly, neither NF- $\mathrm{B}$ nor AP-1 was affected by MPO stimulation, although increases in $\mathrm{NF}-\kappa \mathrm{B}$ activity were observed with asbestos, LPS and PMA. It has previously been reported that both NF- $\kappa \mathrm{B}$ and AP-1 activity increases after exposure to crocidolite asbestos [32, 33], and NF- $\kappa$ B activity has also been demonstrated in lung epithelium after instillation of LPS [34]. More research is needed in order to investigate the transcriptional mechanisms underlying HO-1 expression and cytokine production after exposure of lung epithelial cells to MPO. Other candidate transcription factors involved in $\mathrm{HO}-$ 1 expression are nuclear factor erythroid-2 related factor 2, Bach-1 and hypoxia-inducible factor 1- $\alpha$ [25].

The present study puts forward novel mechanisms of myeloperoxidase action that may be important in the development of lung neutrophilia. However, a limitation of the study is the use of epithelial cell lines, which may have lost some of their in vivo properties. Therefore, future studies using primary epithelial cell cultures, as well as studies using in vivo models of acute lung inflammation, will be necessary to investigate the role of myeloperoxidase in the development of neutrophilic lung inflammation. For example, studies using myeloperoxidase(-/-) versus wild-type mice have demonstrated a role for myeloperoxidase in a chrysotile asbestos-induced model of lung inflammation. The recruitment of neutrophils was significantly delayed in myeloperoxidase(-/-) as compared with wild-type mice [35]. In summary, the present study demonstrates that lung epithelial cells in close proximity to fully activated and degranulated neutrophils are possible target cells for myeloperoxidase. In these cell types, myeloperoxidase induced the expression of haemoxigenase- 1 and increased DNA strand breakage, but has inhibitory effects on the production of pro-inflammatory chemokines interleukin- 6 and -8 during homeostasis and secondary to phorbol 12-myristate 13-acetate exposure.

\section{ACKNOWLEDGEMENTS}

The authors would like to thank M. Kelders (Dept of Respiratory Medicine, University Hospital Maastricht, Maastricht, The Netherlands) for his technical assistance, R-J. van Suylen (Dept of Pathology, University Hospital Maastricht, Maastricht, The Netherlands) for histological advice and E. Verbeken (Dept of Morphology and Molecular Pathology, Leuven University, Leuven, Belgium) for material support.

\section{REFERENCES}

1 Peleman RA, Rytilä PH, Kips JC, Joos GF, Pauwels RA. The cellular composition of induced sputum in chronic obstructive pulmonary disease. Eur Respir J 1999; 13: 839-843.

2 Mossman BT, Churg A. Mechanisms in the pathogenesis of asbestosis and silicosis. Am J Respir Crit Care Med 1998; 157: 1666-1680

3 Hunninghake GW, Gadek JE, Lawley TJ, Crystal RG. Mechanisms of neutrophil accumulation in the lungs of patients with idiopathic pulmonary fibrosis. J Clin Invest 1981; 68: 259-269.

4 Tate RM, Repine JE. Neutrophils and the adult respiratory distress syndrome. Am Rev Respir Dis 1983; 128: 552-559.

5 Medan D, Wang L, Yang X, Dokka S, Castranova V, Rojanasakul Y. Induction of neutrophil apoptosis and secondary necrosis during endotoxin-induced pulmonary inflammation in mice. J Cell Physiol 2002; 191: 320-326.

6 Klebanoff SJ. Myeloperoxidase: friend and foe. J Leukoc Biol 2005; 77: 598-625.

7 Kawano S, Tatsumi E, Yoneda N, Nagata S, Yamaguchi N. Suppression of gene expression of myeloperoxidase (MPO) by $\gamma$-interferon (IFN- $\gamma$ ) in HL60 cells. Lymphokine Cytokine Res 1993; 12: 81-85.

8 Nauseef WM. Myeloperoxidase deficiency. Hematol Oncol Clin North Am 1988; 2: 135-158.

9 Tobler A, Miller CW, Johnson KR, Selsted ME, Rovera G, Koeffler HP. Regulation of gene expression of myeloperoxidase during myeloid differentiation. J Cell Physiol 1988; 136: 215-225.

10 Klebanoff SJ. Myeloperoxidase. Proc Assoc Am Physicians 1999; 111: 383-389.

11 Gujral JS, Hinson JA, Jaeschke H. Chlorotyrosine protein adducts are reliable biomarkers of neutrophil-induced cytotoxicity in vivo. Comp Hepatol 2004; 3: Suppl. 1, S48.

12 Van Der Vliet A, Nguyen MN, Shigenaga MK, Eiserich JP, Marelich GP, Cross CE. Myeloperoxidase and protein 
oxidation in cystic fibrosis. Am J Physiol Lung Cell Mol Physiol 2000; 279: L537-L546.

13 Lau D, Mollnau H, Eiserich JP, et al. Myeloperoxidase mediates neutrophil activation by association with CD11b/ CD18 integrins. Proc Natl Acad Sci USA 2005; 102: 431-436.

14 Lefkowitz DL, Mills KC, Moguilevsky N, Bollen A, Vaz A, Lefkowitz SS. Regulation of macrophage function by human recombinant myeloperoxidase. Immunol Lett 1993; 36: 43-49.

15 Yang JJ, Preston GA, Pendergraft WF, et al. Internalization of proteinase 3 is concomitant with endothelial cell apoptosis and internalization of myeloperoxidase with generation of intracellular oxidants. Am J Pathol 2001; 158: 581-592.

16 Faurschou M, Borregaard N. Neutrophil granules and secretory vesicles in inflammation. Microbes Infect 2003; 5: 1317-1327.

17 Zabucchi G, Soranzo MR, Menegazzi R, Bertoncin P, Nardon E, Patriarca P. Uptake of human eosinophil peroxidase and myeloperoxidase by cells involved in the inflammatory process. J Histochem Cytochem 1989; 37: 499-508.

18 Tiruppathi C, Naqvi T, Wu Y, Vogel SM, Minshall RD, Malik AB. Albumin mediates the transcytosis of myeloperoxidase by means of caveolae in endothelial cells. Proc Natl Acad Sci USA 2004; 101: 7699-7704.

19 Kampf C, Roomans GM. Effects of hypochlorite on cultured respiratory epithelial cells. Free Radic Res 2001; 34: 499-511.

20 Schraufstätter I, Hyslop PA, Jackson JH, Cochrane CG. Oxidant-induced DNA damage of target cells. J Clin Invest 1988; 82: 1040-1050.

21 Hansen K, Mossman BT. Generation of superoxide $\left(\mathrm{O}_{2}^{-}\right)$ from alveolar macrophages exposed to asbestiform and nonfibrous particles. Cancer Res 1987; 47: 1681-1686.

22 Janssen YM, Marsh JP, Absher MP, et al. Oxidant stress responses in human pleural mesothelial cells exposed to asbestos. Am J Respir Crit Care Med 1994; 149: 795-802.

23 Nagatomo H, Morimoto Y, Oyabu T, et al. Expression of heme oxygenase- 1 in the lungs of rats exposed to crocidolite asbestos. Inhal Toxicol 2005; 17: 293-296.

24 Dennery PA. Regulation and role of heme oxygenase in oxidative injury. Curr Top Cell Regul 2000; 36: 181-199.
25 Ryter SW, Choi AM. Heme oxygenase-1: redox regulation of a stress protein in lung and cell culture models. Antioxid Redox Signal 2005; 7: 80-91.

26 Kang W, Nielsen O, Fenger C, et al. The scavenger receptor, cysteine-rich domain-containing molecule gp-340 is differentially regulated in epithelial cell lines by phorbol ester. Clin Exp Immunol 2002; 130: 449-458.

27 Simeonova PP, Luster MI. Asbestos induction of nuclear transcription factors and interleukin 8 gene regulation. Am J Respir Cell Mol Biol 1996; 15: 787-795.

28 Simeonova PP, Toriumi W, Kommineni C, et al. Molecular regulation of IL-6 activation by asbestos in lung epithelial cells: role of reactive oxygen species. J Immunol 1997; 159: 3921-3928.

29 Schulz C, Farkas L, Wolf K, Kratzel K, Eissner G, Pfeifer M. Differences in LPS-induced activation of bronchial epithelial cells (BEAS-2B) and type II-like pneumocytes (A-549). Scand J Immunol 2002; 56: 294-302.

30 Li LF, Ouyang B, Choukroun G, et al. Stretch-induced IL-8 depends on c-Jun $\mathrm{NH}_{2}$-terminal and nuclear factor- $\mathrm{\kappa B}$ inducing kinases. Am J Physiol Lung Cell Mol Physiol 2003; 285: L464-L475.

31 Zhang Y, Broser M, Rom W. Activation of the interleukin 6 gene by Mycobacterium tuberculosis or lipopolysaccharide is mediated by nuclear factors NF-IL6 and NF-кB. Proc Natl Acad Sci USA 1994; 91: 2225-2229.

32 Heintz NH, Janssen YM, Mossman BT. Persistent induction of c-fos and c-jun expression by asbestos. Proc Natl Acad Sci USA 1993; 90: 3299-3303.

33 Janssen YM, Barchowsky A, Treadwell M, Driscoll KE, Mossman BT. Asbestos induces nuclear factor $\kappa \mathrm{B}(\mathrm{NF}-\kappa \mathrm{B})$ DNA-binding activity and NF- $\kappa \mathrm{B}$-dependent gene expression in tracheal epithelial cells. Proc Natl Acad Sci USA 1995; 92: 8458-8462.

34 Poynter ME, Irvin CG, Janssen-Heininger YM. A prominent role for airway epithelial NF- $\kappa \mathrm{B}$ activation in lipopolysaccharide-induced airway inflammation. J Immunol 2003; 170: 6257-6265.

35 Haegens A, van der Vliet A, Butnor KJ, et al. Asbestosinduced lung inflammation and epithelial cell proliferation are altered in myeloperoxidase-null mice. Cancer Res 2005; 65: 9670-9677. 